УДК 159.922 .2

DOI https://doi.org/10.26661/2310-4368/2021-4-5

\title{
ОСОБЛИВОСТІ ОСОБИСТІСНОГО БЛАГОПОЛУЧЧЯ КУРСАНТІВ АКАДЕМІЇ ДЕРЖАВНОЇ ПЕНІТЕНЦІАРНОЇ СЛУЖБИ В УМОВАХ ПАНДЕМІЇ
}

\author{
Данильченко Т. В. \\ доктор психологічних наук, дочент, \\ професор кафедри психології \\ Академія Державної пенітенціарної служби \\ вул. Гонча, 34, Чернігів, Україна \\ orcid.org/0000-0001-8809-0132 \\ dan20151975@gmail.com
}

Ключові слова: особистісне благополуччя, суб' 'ктивне благополуччя, суб'єктивне сочіальне благополуччя, психологічне благополуччя, пандемія, курсанти.
У статті йдеться про особливості особистісного благополуччя курсантів в умовах пандемії. Особистісне благополуччя розглядається як екзистенційний мультиконцепт, що відображає баланс між пошуком суб'єктом задоволення (позитивних емоцій) у різних життєвих сферах згідно з імпліцитною концепцією благополуччя та розкриттям особистісного потенціалу й досягнення гармонії між внутрішнім i зовнішнім світом, на основі базових емоційних характеристик особистості і позитивних рис характеру.

Курсанти, що перебувають у специфічних умовах навчання, переживають тиск як із боку навчального закладу (акцент оцінювання і порівняння, нормованість та жорстка організація життєвого простору), так і з боку соціального середовища (контактні обмеження, пов'язані з пандемію COVID-19, дистанційне навчання). Тому перевірялося припущення про зниження благополуччя особистості.

У дослідженні взяли участь курсанти Академії Державної пенітенціарної служби: 60 осіб (30 хлопців і 30 дівчат) у вересні - листопаді 2019 року, 106 осіб (43 дівчини і 63 хлопці) у вересні - жовтні 2021 року.

Спостережені такі особливості. По-перше, рівень суб'єктивного (афективного) благополуччя не змінився («задоволений незначною мірою») - відбулася гедоністична адаптація. По-друге, виявлені статеві відмінності у змінах суб'єктивного соціального благополуччя. Не змінилася емоційна оцінка стосунків із близьким колом спілкування та пошук соціального схвалення в курсанток. У юнаків-курсантів підвищились значущість соціальних зв'язків та потреба в активній участі у групових процесах. По-трете, психологічне благополуччя зросло: до початку пандемії в курсантів, як юнаків, так і дівчат, воно було нижче, ніж в її активний період. Особливі зміни стосувалися розуміння життєвих цілей - відбулася актуалізація побудови життевих планів у ситуації пандемічної невизначеності. Також зафіксоване підвищення показників особистісного зростання та компетентності, оскільки ситуація пандемії дала можливість отримати новий досвід і віднайти більш ефективні форм поведінки.

Рівень переживання загального особистісного благополуччя статистично достовірно підвищився: особи 3 його високим рівнем становили $25,8 \%$ до пандемії і 38,7 \% під час її перебігу. 


\title{
FEATURES OF THE PERSONAL WELL-BEING OF CADETS OF THE ACADEMY OF SPS IN THE CONDITION OF THE PANDEMIC
}

\author{
Danylchenko T. V. \\ Doctor of Psychological Sciences, Associate Professor, \\ Professor at the Department of Psychology \\ Academy of the State Penitentiary Service \\ Goncha str., 34, Chernihiv, Ukraine \\ orcid.org/0000-0001-8809-0132 \\ dan20151975@gmail.com
}

Key words: personal well-being, subjective well-being, subjective social well-being, psychological well-being, pandemic, cadets.
The article discusses features of the personal well-being of cadets in the pandemic. Personal well-being is considered as an existential multi-concept that displays the balance between the subject's pursuit of pleasure (positive emotions) in various spheres of life according to the implicit concept of well-being and unlocking personal potential and harmony between inner and external worlds grounded on basic emotional characteristics of an individual and positive character traits.

Being in specific learning conditions, cadets experience pressure from both the education institution (emphasis on assessment and comparison, standardization and rigid organization of living space) and the social environment (contact restrictions due to the COVID-19 pandemic, distance learning). Therefore, the hypothesis on reduced personal well-being has been tested.

Cadets of the Academy of the State Penitentiary Service have participated in the study: 60 persons (30 males and 30 females) in September - November, 2019; 106 persons (43 females and 63 males) in September - October, 2021. The following features are observed. First, the level of subjective (affective) well-being has not changed ("slightly satisfied") - hedonistic adaptation has taken place. Second, gender differences in changes of subjective social wellbeing have been found. The emotional assessment of relations with close circle and the search for social approval of cadets has remained the same. In male cadets, the importance of social networks and the need for active participation in group processes has increased. Third, psychological well-being has advanced: before the pandemic, it was lower in both male and female cadets than in its active period. Specific changes are associated with the understanding of life goals - the actualization of life plans amidst pandemic uncertainty has occurred. The study has also fixed an increase in personal growth and competence, as the pandemic situation allowed gaining new experience and finding more effective forms of conduct.

The level of general personal well-being has significantly increased in terms of statistics: persons with its high level were $25,8 \%$ before the pandemic and $38,7 \%$ during the pandemic.
Постановка проблеми. Феномен благополуччя привернув увагу науковців наприкінці XX ст. Самопочуття окремої людини стало не тільки індивідуальною справою, але й привернуло увагу суспільства. Країни стали конкурувати за вищі щаблі в різноманітних рейтингах щастя / якості життя / благополуччя / процвітання. В умовах пандемії, що викликала трансформацію суспільних і особистих цінностей, а також зміни адаптивних форм поведінки, питання збереження рівня благополуччя стало виразною психологічною і суспільною проблемою. Ідея позитивної психології про те, що в кожної людини досить психологічних ресурсів, щоб підвищити власне благополуччя, в умовах зниження контактності та підвищення соціального навантаження на державу виявилася досить привабливою. Однак для запровадження практик із підвищення благополуччя необхідно з'ясувати його структуру та виявити чинники, що на нього впливають. 
Особливу роль у процесі побудови імпліцитної концепції благополуччя особистістю завжди відігравали інститути соціалізації, зокрема навчальні заклади. На жаль, типовими для педагогіки залишається постійне оцінювання і соціальне порівняння. Однак виявлено, що ці процеси знижують благополуччя [1]. Зазначимо, що останнім часом у багатьох країнах прийшли до ідеї засвоєння у школах та вишах «мистецтва бути щасливим» у вигляді окремої навчальної дисципліни. Курсанти, що перебувають у специфічних умовах навчання, піддаються подвійному тиску. 3 одного боку, вони перебувають в умовах типової для навчальних закладів негативної соціалізації (акцентованої на покаранні та порівнянні), із другого - мають постійну нормованість та жорстку організацію життєвого простору. Останнім часом додався ще один чинник - це обмеження, пов'язані $з$ пандемію COVID-19 (дистанційне навчання, обмеження контактів, зниження можливостей забезпечити свої потреби). У таких умовах можна припустити зниження благополуччя особистості, а тому останнє вимагає постійного моніторингу та ведення психологічного супроводу курсантів.

Поняття «особистісне благополуччя» було запропоноване російськими дослідниками М.О. Батуріним, С.О. Башкатовим, Н.В. Гафаровою. Вони описали цей феномен як «специфічне поєднання властивостей темпераменту, особистості і позитивних рис характеру, що забезпечують людині умови для того, щоб здійснювати позитивні вчинки, мати благополучні міжособистісні стосунки, глобальне позитивне ставлення до себе і світу» [2, с. 7]. У вітчизняній психології поняття особистісного благополуччя не надто поширене. Теоретичну концепцію запропонувала Н.В. Волинець, яка особистісне благополуччя вважає «інтегральною рефлексивною оцінкою суб'єктом якості власного життя і життєдіяльності загалом» $[3$, c. 2].

На нашу думку, особистісне благополуччя - це узагальнюючий (зонтичний) концепт для цілої низки понять, що описують оптимальне функціонування людини (щастя, процвітання, позитивне самопочуття, психологічний комфорт тощо). Ми визначили особистісне благополуччя як екзистенційний мультиконцепт, що відображає баланс між пошуком суб'єктом задоволення (позитивних емоцій) у різних життєвих сферах згідно з імпліцитною концепцією благополуччя та розкриттям особистісного потенціалу й досягнення гармонії між внутрішнім і зовнішнім світом, на основі базових емоційних характеристик особистості і позитивних рис характеру [4]. Його складовими частинами вважаємо суб'єктивне соціальне благополуччя, суб' єктивне (афективне, гедоністичне, емоційно-особистісне) благополуччя і психо- логічне (евдемонічне) благополуччя. Емоційне благополуччя - збіг очікувань і життєвих подій, на основі чого виникає задоволення власним життям. Психологічне благополуччя - потенціал людини вести значуще життя та справлятися із проблемами. Суб'єктивне соціальне благополуччя - оцінка соціального функціонування на основі співвідношення рівня домагань і ступеня задоволення соціальних потреб [5].

Особистісне благополуччя студентів вивчалося мало, що пов'язано 3 відносною новизною наукових розвідок щодо самого феномену особистісного благополуччя [6; 7]. Серед останніх вітчизняних досліджень - робота Н.В. Волинець, присвячена вивченню особистісного благополуччя персоналу Державної прикордонної служби України [3]. Авторка розробила фокусовано-холістичну модель особистісного благополуччя, у яку включено три фокуси-компоненти: особистісний, професійний і організаційний.

Набагато більше праць, присвячених окремим аспектам особистісного благополуччя. Так, суб'єктивне благополуччя студентів досліджували Ю.А. Гімаєва та К.О. Малофейкіна [8], а його психологічні чинники вивчали О.Б. Дубчак i Т. Чубата [9].

Психологічне благополуччя студентів-психологів представлено в палітрі наукових розвідок досить розлого. Так, вивчалося психологічне благополуччя загалом [10-12] та його окремі аспекти. Гендерна специфіка представлена у праці I.Н. Габи [13] і С.Б. Жарікової [14]. Також виявлені такі чинники психологічного благополуччя студентів: життєстійкість (Н.В. Гранкіна-Сазонова [15]), особистісна спрямованість (А.С. Харченко, Н.О. Гончарова [16]), мотивація досягнення (О.Б. Ігумнова, Л.М. Джигун, А.І. Руденок [17]). Аналіз загальних чинників переживання благополуччя студентами представлено у праці Л.З. Сердюк [18]. 3'ясовані особливості набуття психологічного благополуччя студентами з обмеженими можливостями (О.В. Гуляєва [19]). Здійснені перші спроби висвітлити специфіку його переживання під час пандемії [20].

Цікавою $з$ погляду концепції особистісного благополуччя здається робота О.М. Поліщук i Т.А. Колтунович, у якій досліджуються зв'язки між психологічним і суб'єктивним благополуччям у студентів [21].

Дослідження суб'єктивного соціального благополуччя представлено обмежено [22], оскільки останне - порівняно новий предмет наукової уваги, хоча, безумовно, роль соціального середовища не відкидається. Однак розуміння, що специфіка переживання соціальних зв'язків може трактуватися як окремий феномен психіки, з'явилося на межі століть. 
Дослідження благополуччя курсантів, що перебувають у специфічних умовах навчання, порівняно нечисленні $[5 ; 23 ; 24]$, тому метою дослідження $є$ 3'ясування особливостей особистісного благополуччя курсантів в умовах пандемії.

Методи дослідження. Були використані такі методики: Шкала суб'єктивного соціального благополуччя [25]; Шкала задоволеності життям Е. Дінера [26]; Шкала психологічного благополуччя К. Ріфф в адаптації Л.В. Жуковської, Є.Г. Трошихіної [27]. У дослідженні взяли участь курсанти Академії Державної пенітенціарної служби (м. Чернігів). Дослідження проходило у два етапи. Перший етап (доковідний) був проведений у вересні - листопаді 2019 р. (30 хлопців i 30 дівчат), другий етап дослідження був реалізований у вересні - жовтні 2021 р. (43 дівчини і 63 хлопці).

Аналіз результатів. Загалом, особистісне благополуччя в умовах пандемічних змін виявилося на досить високому рівні. Так, середній показник емоційного благополуччя, що відображає баланс позитивного і негативного афекту та задоволеність життям, виявився навіть вищим (хоча статистично значущих відмінностей і не зафіксовано). В останньому вимірюванні він становив (М) 23,96 балів - «задоволений незначною мірою» на противагу 22 балам у 2019 р. Отже, можемо зробити висновок, що відбулася адаптація до наявного стану і рівень задоволеності життям стабілізувався. Ця закономірність підтверджується результатами іншого нашого дослідження 2020 р., де виявлено, що умови пандемії суттєво не вплинули на переживання особистісного благополуччя українцями [28]. Рівень усіх його складових частин (емоційна, психологічна та соціальна) залишився без змін. Спостерігалися незначні коливання, що вкладалися в межі статистичної похибки.

Відзначимо, що показники суб' єктивного соціального благополуччя (далі - ССБ) статистично вищі у другому зрізі (під час епідемії). Однак зазначимо, що виявлено статеві відмінності: рівень ССБ не змінився у дівчат-курсанток, однак підвищився в юнаків-курсантів $(\mathrm{p} \leq 0,01)$.

Загалом, показники суб' єктивного соціального благополуччя, що відображають задоволення соціальними відносинами різного типу, досить високі. Так, у другому зрізі низький рівень ССБ (до 3 стенів) виявлено всього в 7,5\% опитаних, тоді як високий рівень (вище 7 стенів) зафіксовано в $52,8 \%$ респондентів. Емоційне прийняття, соціальна помітність та схвалення по всій вибірці в середньому становлять 7 стенів, а позитивні соціальні судження - 6 стенів.

Найбільші розбіжності за показниками суб'єктивного соціального благополуччя були виявлені в чоловіків (табл. 1). У другому зрізі зафіксовано суттєво вищий рівень соціальної помітності в юнаків. Якщо у 2019 р. в них більше проявляється «соціальна мімікрія», тобто бажання покластися у групових рішеннях на думку інших членів спільноти, притаманні уявлення, що в них відсутні важелі впливу на процеси, які відбуваються у групі, то у 2021 р. юнаки більше прагнуть до активної участі в діяльності групи і мають бажання впливати на процеси, що в ній відбуваються (47 балів - 7 стенів). Також зафіксовано статистично достовірні відмінності за рівнем соціальної дистантності. У 2019 р. в юнаків вона була суттєво вищою порівняно із 2021 р. Можемо припустити, що наявність карантинних обмежень актуалізувала потребу в соціальній зв'язності та підвищила їі цінність. Це припущення підтверджується збільшенням рівня емоційного прийняття з боку близьких у юнаків.

Отже, можемо зробити висновок, що переживання соціальної зв'язності та задоволення від взаємин не змінилися під впливом карантинних обмежень у курсанток жіночої статі, однак актуалізували значущість соціальних зв'язків та

Таблиця 1

Порівняння показників суб' єктивного та суб'єктивного соціального благополуччя в курсантів (M)

\begin{tabular}{|c|c|c|c|c|c|}
\hline & $\mathbf{p}$ & \multicolumn{2}{|c|}{$\mathbf{2 0 1 9}$ р. } & \multicolumn{2}{c|}{$\mathbf{2 0 2 1}$ р. } \\
\hline & & чоловіки & жінки & чоловіки & жінки \\
\hline Соціальна помітність & 0,01 & $40,14 \downarrow / 6^{*}$ & $43,74 / 6$ & $47,0 \uparrow / 7$ & $43,86 / 6$ \\
\hline Соціальна дистантність & 0,01 & $20,24 \uparrow / 5$ & $18,48 / 5$ & $16,65 \downarrow / 4$ & $18,19 / 5$ \\
\hline Емоційне прийняття & 0,05 & $39,86 \downarrow / 6$ & $40,06 / 6$ & $42,90 \uparrow / 7$ & $40,56 / 6$ \\
\hline Соціальне схвалення & - & $32,62 / 6$ & $36,08 / 6$ & $36,68 / 7$ & $36,72 / 6$ \\
\hline Позитивні соціальні судження & - & $17,82 / 6$ & $19,72 / 6$ & $17,95 / 6$ & $17,42 / 5$ \\
\hline ССБ (загальний показник) & 0,01 & $109,45 \downarrow / 6$ & $120,54 / 6$ & $127,89 \uparrow / 7$ & $120,37 / 6$ \\
\hline Суб’єктивне благополуччя & - & 21,62 & 22,66 & $24,67 \uparrow$ & 22,93 \\
\hline
\end{tabular}

*-стени. 
потребу в активній участі у групових процесах у курсантів чоловічої статі.

У результаті вивчення психологічного / евдемонічного благополуччя були отримані парадоксальні дані: до початку пандемії в опитаних курсантів воно було статистично достовірно нижчим, ніж у період пандемії (таблиця 2). Так, у період пандемії загальний показник психологічного благополуччя становив 206,27 балів, тоді як у першому зрізі - тільки 188,73 бали. Ми нині можемо висловити тільки припущення, що потребує подальшої емпіричної перевірки. Оскільки на момент проведення другого опитування існування в режимі пандемічних обмежень тривало вже півтора року, то респонденти адаптувалися до наявної ситуації і стали сприймати іiі як звичний стан. Дослідники визначають цей процес як «гедоністична адаптація» [29]. Окрім того, імовірним $\epsilon$ підвищення відчуття ресурсності: людина справляється із ситуацією, яку ЗМК і соціальне оточення визначають як складну, небезпечну, стресову. Відповідно зростають самооцінка та відчуття компетентності. Причому цей процес більш виражений у юнаків, порівняно $з$ дівчатами. Можливо, здатність до керування ситуацією відповідає традиційним маскулінним характеристикам, а тому підкріплює їхню гендерну ідентичність.

Найбільші відмінності - 3 стенайни - були зафіксовані за параметром «Життєві цілі». Імовірним поясненням, на нашу думку, є актуалізація побудови життєвих планів у ситуації невизначеності. Ця характеристика пов'язана з усвідомленням свого минулого та теперішнього, відчуття мети життя. Для юнацького віку характерний пошук життєвого призначення. За Е. Еріксоном, головним життєвим завданням у віці $12-20$ років (юність) є пошук сенсу життя та формування его-ідентичності [30]. Однак особливістю цього процесу є його кризове проходження, на першому етапі відмова від самовизначення, формування «негативної» ідентичності. Це явище можемо спостерігати в першому зрізі. Незважаючи на те, що вік опитуваних у першому і другому зрізах однаковий, можемо бачити більшу психологічну зрілість у другому випадку. Імовірно, «катастрофізація» соціально-психологічного середовища привела до прискорення процесів формування особистісної зрілості, що важливо у кризовий період як для суспільства загалом, так і для особистості зокрема.

Подібна тенденція спостерігається в чоловічої частини вибірки (різниця 2 стенайни) і щодо параметрів особистісного зростання, компетентності та самоприйняття.

Ситуація пандемії однозначно розширила можливості особистісного зростання, яке трактується в даному підході як засвоєння нового досвіду та зміни в поведінці, що ведуть до більш ефективного вирішення повсякденних завдань. У цьому контексті людство загалом зіткнулося з абсолютно новими завданнями і шляхом проб (інколи невдалих) намагається їх розв'язати. Ситуація пандемії так чи так відбилася на кожній життєвій історії і змусила вийти за межі звичного повсякденного досвіду, шукати нові способи реалізації життєвого потенціалу. Конкретним прикладом для студентів вишів $є$ адаптація до дистанційного навчання. Тому цілком природно, що для другої групи характерне відчуття реалізації власного потенціалу і переживання розвитку, що триває. Зазначимо, що непрямим підтвердженням цієї гіпотези $€$ і той факт, що за показниками особистісного зростання чоловічі та жіночі групи не відрізняються: середні - у 2019 р. і вище середнього - у 2021 р. Аналогічно можемо пояснити і відмінності в компетентності, яку К. Ріфф описує як здатність обирати або створювати сприятливий контекст для реалізації особистих потреб і цінностей [31].

Дещо вибивається із загального контексту характеристика самоприйняття, тому що вона

Таблиця 2

Порівняння показників психологічного благополуччя (М)

\begin{tabular}{|c|c|c|c|c|c|}
\hline & $\mathbf{p}$ & \multicolumn{2}{|c|}{$\mathbf{2 0 1 9} \mathbf{p .}$} & \multicolumn{2}{c|}{$\mathbf{2 0 2 1}$ p. } \\
\hline & & чоловіки & жінки & чоловіки & жінки \\
\hline Автономія & 0,01 & $30,80 \downarrow / 5^{*}$ & $29,82 \downarrow / 5$ & $32,62 \uparrow / 6$ & $32,51 \uparrow / 6$ \\
\hline Компетентність & 0,05 & $28,96 \downarrow / 5$ & $28,92 \downarrow / 5$ & $33,51 \uparrow / 7$ & $31,49 / 6$ \\
\hline Особистісне зростання & 0,01 & $34,32 \downarrow / 5$ & $34,12 \downarrow / 5$ & $36,24 \uparrow / 7$ & $36,77 \uparrow / 6$ \\
\hline Позитивні стосунки & 0,01 & $32,24 \downarrow / 4$ & $34,30 / 5$ & $35,56 \uparrow / 6$ & $34,84 / 5$ \\
\hline Життєві цілі & 0,01 & $30,62 \downarrow / 3$ & $30,28 \downarrow / 3$ & $36,29 \uparrow / 6$ & $37,02 \uparrow / 6$ \\
\hline Самоприйняття & 0,01 & $31,38 \downarrow / 4$ & $31,68 \downarrow / 4$ & $33,13 \uparrow / 6$ & $32,09 / 5$ \\
\hline $\begin{array}{c}\text { Психологічне благополуччя } \\
\text { (загальний показник) }\end{array}$ & 0,01 & $188,32 \downarrow / 4$ & $189,30 \downarrow / 4$ & $207,33 \uparrow / 7$ & $204,72 \uparrow / 6$ \\
\hline
\end{tabular}

*- стенайни;

$\downarrow \uparrow-$ групи, які на статистично значущому рівні мають відмінності. 
залежить від ставлення до минулого. Ситуація пандемії ще не перейшла для курсантів у статус минулого, однак виявлено збільшення самоприйняття на два стенайни у хлопців і на один у дівчат. На нашу думку, ця тенденція вимагає подальших досліджень, що будуть спрямовані на виявлення чинників зазначеного процесу.

Не змінилася емоційна оцінка стосунків із близьким колом спілкування в дівчат: вона як була середньою, так і залишилася. Тоді як юнаки другого зрізу оцінюють свої близькі взаємини як більш сприятливі. Зазначимо, що за шкалою емоційного прийняття (ССБ), яка перетинається за смисловим контекстом із позитивними стосунками, ситуація аналогічна: не змінилася в курсанток, достовірно вища в курсантів.

Найменші відмінності за показником автономіі: нижчий рівень у всіх респондентів у 2019 р. i вищий - у 2021 p. Він описує міру опору соціальному тиску i здатності до самовизначення i незалежності. Зазначимо, що соціальний тиск у вигляді інформаційного навантаження, примусу до вакцинації i носіння маски, низки заборон щодо відвідування публічних місць дає можливість усвідомити міру самостійності в ухваленні рішень, що стосуються захисту власного життя в буквальному сенсі.

Для 3'ясування особливостей переживання особистісного благополуччя курсантами під час пандемії був використаний факторний i кластерний аналіз (статистичний пакет SPSS Statistics 22.0). На першому етапі була виявлена статистична вага складових частин особистісного благополуччя. У структурі, що пояснила 73,10\% загальної дисперсії, на першому місці виявилося психологічне благополуччя (факторне навантаження - 0,879), на другому - суб'єктивне соціальне благополуччя $(0,865)$, на третьому - емоційне (суб'єктивне) благополуччя $(0,820)$. На другому етапі був здійснений кластерний аналіз за допомогою k-середніх вищевказаних змінних у зазначеному порядку. Було виділено три кластери (групи). Статистичний рівень відмінностей (p) за всіма показниками - 0,01. Результати представлені в таблиці 3.

Таблиця 3

Порівняння розподілу курсантів за типами переживання особистісного благополуччя

\begin{tabular}{|c|c|c|c|}
\hline & $\begin{array}{c}\text { Неблаго- } \\
\text { получні }\end{array}$ & $\begin{array}{c}\text { Благо- } \\
\text { получні }\end{array}$ & $\begin{array}{c}\text { Високоблаго- } \\
\text { получні }\end{array}$ \\
\hline 2019 р. & $20,0 \%$ & $54,2 \%$ & $25,8 \%$ \\
\hline 2021 р. & $14,2 \%$ & $47,2 \%$ & $38,7 \%$ \\
\hline
\end{tabular}

Отже, можемо зробити висновок, що на статично достовірному рівні (критерій $\chi^{2}$ Пірсона) зафіксовано вищий рівень особистісного благополуччя під час другого зрізу даних (пандемічний період). На нашу думку, суттєві зміни організації життя під час пандемії привели до актуалізації усвідомлення значущості соціальних стосунків та власних зусиль в організації життєвого простору. Вихід із зони комфорту супроводжувався збільшенням відчуття власної компетентності та важливості особистого вибору в ситуації невизначеності.

Висновки. Особистісне благополуччя ми вважаємо складним утворенням, що відображає баланс між пошуком суб'єктом задоволення (позитивних емоцій) у різних життєвих сферах згідно 3 імпліцитною концепцією благополуччя та розкриттям особистісного потенціалу й досягнення гармонії між внутрішнім і зовнішнім світом, на основі базових емоційних характеристик особистості і позитивних рис характеру. Пандемія постала зовнішнім чинником, що суттєво змінив життєвий простір, вплинула на процес переживання благополуччя особистістю. Її вплив тільки починає досліджуватись, а тому окремі категорії, зокрема курсанти, вивчені не досить.

У процесі емпіричного дослідження ми дійшли таких висновків. По-перше, рівень суб' єктивного (афективного) благополуччя не змінився. За півтора року відбулося прийняття нової життєвої ситуації і проявилася гедоністична адаптація.

По-друге, виявлено статеві відмінності у змінах суб'єктивного соціального благополуччя. Не змінилася емоційна оцінка стосунків із близьким колом спілкування та пошук соціального схвалення в курсанток. У юнаків-курсантів підвищилась значущість соціальних зв'язків та потреба в активній участі у групових процесах.

По-третє, евдемонічне благополуччя підвищилось: до початку пандемії у курсантів, як юнаків, так і дівчат, воно було нижче, ніж в іï активний період. Особливі зміни відбулися в розумінні життєвих цілей, особистісному зростанні, компетентності та самоприйнятті. Ситуація пандеміі стала поштовхом для особистісного зростання як набуття нового досвіду і пошуку більш ефективних форм поведінки. Також вона сприяла актуалізації автономії як опору інформаційному навантаженню і вибору індивідуальної стратегії поведінки щодо вакцинації та використання захисних засобів.

Отже, на противагу очікуваному зниженню особистісного благополуччя, виявлені ресурсні можливості для курсантів складних життєвих обставин, пов'язаних з епідемією COVID-19.

Перспективи дослідження вбачаємо в 3'ясуванні причин розбіжностей переживання особистісного благополуччя в курсантів чоловічої статі, а також у порівнянні динаміки його переживання курсантами 3 іншими категоріями (студенти, молодь, яка працює, та інші). 


\section{ЛІТЕРАТУРА}

1. Бонивелл И. Ключи к благополучию: Что может позитивная психология. Москва : Время, 2009. 192 с.

2. Батурин Н.А., Башкатов С.А., Гафарова Н.В. Теоретическая модель личностного благополучия. Вестник Южно-Уральского государственного университета. Серия «Психология». 2013. Т. 6. № 4. C. 4-14.

3. Волинець Н.В. Психологія особистісного благополуччя персоналу Державної прикордонної служби України : дис. ... докт. псих. наук : 19.00.01. Київ, 2020. 543 с.

4. Данильченко Т.В. Місце поняття «особистісне благополуччя» в системі категорій позитивної психології. Науковий вісник Сіверщини. Серія «Освіта. Соиіальні та поведінкові науки». 2020. № 2(5). C. 52-69. DOI: /10.32755/sjeducation.2020.02.052.

5. Данильченко Т.В. Особливості особистісного благополуччя студентів в специфічних умовах навчання. Актуальні питання теорії та практики в галузі права, освіти, сочіальних та поведінкових наук - 2020 : матеріали Міжнародної науково-практичної конференції, м. Чернігів, 23-24 квітня 2020 р. : у 2 т. Т. 1 : Академія Державної пенітенціарної служби. Чернігів : Академія ДПтС, 2020. С. 224-228.

6. Данильченко Т.В. Сравнительный анализ личностного благополучия украинских и белорусских студентов. Вестник Полоцкого государственного университета. Серия Е «Педагогические науки. Психология». 2020. № 7. С. 49-54.

7. Карапетян Л.В., Глотова Г.А. Исследование параметров эмоционально-личностного благополучия российских студентов (окончание). Вестник Московского университета. Серия 14 «Психология». 2018. № 3. С. 60-75.

8. Гімаєва Ю.А., Малофейкіна К.О. Особистісна зрілість та суб'єктивне благополуччя у студентів денної та заочної форм навчання в університеті. Вісник Харківського національного університету імені В.Н. Каразіна. Серія «Психологія». 2019. Вип. 67.C. 15-24. DOI: 10.26565/2225-7756-2019-67-02

9. Дубчак О.Б., Чубата Т. Психологічні чинники переживання почуття суб'єктивного благополуччя студентами-психологами. Вісник Національного авіаџійного університету. Серія «Педагогіка. Психологія». 2019. № 15. С. 123-130.

10. Срмолаєва Є.С. Параметри психологічного благополуччя студентів. Науковий вісник Херсонського державного університету. 2017. Вип. 4. Т. 2. С. 36-40.

11. Данилюк I.В., Купрєєва О.І. Психологічне благополуччя в просторі самореалізації студентської молоді. Щастя та сучасне суспільство : збірник матеріалів Міжнародної наукової конференції, м. Львів, 20-21 березня 2020 р. Львів : СПОЛОМ, 2020. С. 63-66.

12. Березовська Л.І., Туркіна К.Г. Психологічне благополуччя майбутніх психологів. Психологія національної безпеки $i$ благополуччя особистості : тези I Міжнародної науково-практичної конференції, 14-15 березня 2019 р., м. Львів. Львів : Видавництво Львівської політехніки, 2019. C. 201-203.

13. Габа І.Н. Психологічне благополуччя студентської молоді: гендерний аспект. Теорія $i$ практика сучасної психології. 2019. № 1. Т. 1. С. 150-154.

14. Жарікова С.Б. Гендерна специфіка взаємозв'язку психологічного благополуччя та диференційних типів рефлексії у студентів-першокурсників. Теорія і практика сучасної психологї̈. 2019. № 6. Т. 1. C. $43-46$.

15. Гранкіна-Сазонова Н.В. Психологічне благополуччя та життєстійкість студентів-психологів як важливі чинники освоєння професії. Psychological Journal. 2018. № 7(17). С. $23-42$.

16. Харченко А.С., Гончарова Н.О. Особливості психологічного благополуччя студентів із різним типом спрямованості. Психологія і особистість. 2017. № 2(12). С. 186-194.

17. Ігумнова О.Б., Джигун Л.М., Руденок А.І. Психологічне благополуччя майбутніх психологів 3 різними типами мотивації досягнень. Вісник Національного авіаційного університету. Серія «Педагогіка. Психологія». 2020. № 1(16). С. 164-172.

18. Сердюк Л.З. Фактори психологічного благополуччя студентів. Актуальні проблеми психологї : збірник наукових праць Інститут психологїїмені Г.С. Костюка НАПН Украӥни. 2018. Вип. 6. С. 51-59.

19. Гуляєва О.В. Чинники психологічного благополуччя у студентів з обмеженими можливостями здоров'я : дис. ... канд. психол. наук : 19.00.01. Харків, 2018. 207 с.

20. Психологічне благополуччя особистості в період пандемії COVID-19 / І.Г. Тітов та ін. Психологія $i$ особистість. 2020. № 2(18). С. 55-76.

21. Поліщук О.М., Колтунович Т.А. Особливості взаємозв'язку психологічного благополуччя та емоційних переживань студентів-психологів. Ракурси психологічного благополуччя особистості : збірник тез доповідей Всеукраїнського науково-практичного семінару «Ракурси 
психологічного благополуччя особистості», 9 червня 2017 р. Ніжин. Ніжин : НДУ ім. М. Гоголя, 2017. С. 137-141.

22. Данильченко Т.В. Особливості суб'єктивного соціального благополуччя у студентської молоді. Сучасна молодь у соиіально-психологічному вимірі: здобутки чернігівських психологів. Чернігів : Десна Поліграф, 2017. С. 287-304.

23. Коваленко А.Б., Грищук Е.Ю., Рогаль Н.І. Чинники психологічного благополуччя курсантів. Украӥнський психологічний журнал. 2020. № 1(13). С. 85-104.

24. Шеховцова Н.А., Селюкова Т.В. Задоволеність життям і професійною діяльністю майбутніх працівників ДСНС України, які знаходяться під різним стилем керівництва. Особистість, суспільство, закон : тези доповідей учасників Міжнародної науково-практичної конференції, присвяченої пам'яті професора С.П. Бочарової, 24 квітня 2020 р., м. Харків, Україна / МВС України, Харківськ. нац. ун-т внутр. справ. Харків, 2020. С. 321-324.

25. Данильченко Т.В. Питальник «Суб’єктивне соціальне благополуччя»: методологічне обгрунтування і процедура розробки. East European Scientific Journal. 2015. № 3(4). C. 20-29.

26. Осин Е.Н., Леонтьев Д.А. Апробация русскоязычных версий двух шкал экспресс-оценки субъективного благополучия. Материалы III Всероссийского соииологического конгресса. Москва : Институт социологии РАН ; Российское общество социологов, 2008. CD. URL: https://www.hse.ru/ pubs/share/direct/document/78753837 (дата звернення: 23.03.2013).

27. Жуковская Л.В., Трошихина Е.Г. Шкала психологического благополучия К. Рифф. Психологический журнал. 2011. № 2(32). С. 82-93.

28. Данильченко T.B. Переживання особистісного благополуччя на першому етапі пандемії COVID-19 (у друці).

29. Easterlin R.A. Building a Better Theory of Well-Being. Economics and Happiness / L. Bruni, P.L. Porta (Eds.). Oxford : Oxford University Press, 2005. P. 29-64.

30. Эриксон Э. Детство и общество. Москва : Ленато, 1996. 592 с.

31. Ryff C.D., Singer B. Best news yet on the six-factor model of well-being. Social Science Research. 2006. № 35(4). C. 1103-1119.

\section{REFERENCES}

1. Bonivell, I. (2009). Klyuchi k blagopoluchiyu: Chto mozhet pozitivnaya psikhologiya [Keys to well-being: What can positive psychology do?]. M. : Vremya.

2. Baturyn, N.A., Bashkatov, S.A., \& Gafarova, N.V. (2012). Teoreticheskaya model' lichnostnogo blagopoluchiya [Theoretical model of personality well-being]. Vestnyk JuUrGU, Seriya "Psyhologiya", 6 (4), 4-14 [in Russian].

3. Volynets, N.V. (2020). Psykholohiia osobystisnoho blahopoluchchia personalu Derzhavnoi prykordonnoi sluzhby Ukrainy [Psychology of personal well-being of the staff of the State Border Guard Service of Ukraine]. The thesis for getting Doctor degree of psychology sciences. Specialty 19.00.01. Kyiv [in Ukrainian].

4. Danylchenko, T.V. (2020). Misce ponjattja "osobystisne blaghopoluchchia" v systemi kateghorij pozytyvnoji psykhologhiji [The place of the concept of "personal well-being" in the system of categories of positive psychology]. Naukovyj visnyk Sivershhyny. Serija: Osvita. Socialjni ta povedinkovi nauky, 2 (5), 52-69. DOI: 10.32755/sjeducation.2020.02.052 [in Ukrainian].

5. Danylchenko, T.V. (2020). Osoblyvosti osobystisnogho blaghopoluchchia studentiv v specyfichnykh umovakh navchannja [Features of personal well-being of students in specific learning condition]. Aktualjni pytannja teoriji ta praktyky $v$ ghaluzi prava, osvity, socialjnykh ta povedinkovykh nauk - 2020: materialy mizhnar. nauk.-prakt. konf. (m. Chernighiv, 23-24 kvitnja 2020 r.). T. 1 (pp. 224-228). Chernighiv : Akademija Derzhavnoji penitenciarnoji sluzhby [in Ukrainian].

6. Danylchenko, T.V. (2020). Sravnitelnyy analiz lichnostnogo blagopoluchiya ukrainskikh i belorusskikh studentov [Comparative analysis of personal well-being of Ukrainian and Belarusian students]. Vestnik Polotskogo gosudarstvennogo universiteta. Seriya Ye. Pedagogicheskie nauki. Psikhologiya, 7, 49-54 [in Russian].

7. Karapetyan, L.V., \& Glotova, G.A. (2018). Issledovanie parametrov emotsionalno-lichnostnogo blagopoluchiya rossiyskikh studentov (okonchanie) [Study of parameters of emotionally-personality well-being of Russian students (ends)]. Vestnik Moskovskogo universiteta. Seriya 14. Psikhologiya, 3, 60-75 [in Russian].

8. Gimaeva, Yu., \& Malofeykina, K.O. (2019). Osobystisna zrilist ta subiektyvne blahopoluchchia v studentiv dennoi ta zaochnoi formy navchannia $\mathrm{v}$ universyteti [Personal maturity and subjective well-being of 
full-time and part-time students at the university]. Visnyk Kharkivskoho natsionalnoho universytetu imeni V.N. Karazina. Seriia: Psykholohiia, 67, 15-24. doi.org/10.26565/2225-7756-2019-67-02 [in Ukrainian].

9. Dubchak, O.B., \& Chubata, T. (2019). Psykhologhichni chynnyky perezhyvannja pochuttja sub'jektyvnogho blaghopoluchchia studentamy-psykhologhamy [Psychological factors of experiencing the feeling of subjective well-being by students-psychologists]. Visnyk Nacionaljnogho aviacijnogho universytetu. Serija: pedaghoghika. Psykhologhija, 15, 123-130 [in Ukrainian].

10. Yermolaieva, Ye.S. (2017). Parametry psykholohichnoho blahopoluchchia studentiv [Parameters of psychological well-being of students]. Naukovyi visnyk Khersonskoho derzhavnoho universytetu, 4 (2), 36-40 [in Ukrainian].

11. Danyliuk, I.V., \& Kuprieieva, O. (2020). Psykholohichne blahopoluchchia v prostori samorealizatsii studentskoi molodi [Psychological well-being in the space of students' self-realization]. Happiness And Contemporary Society: Conference Proceedings Volume (Lviv, March, 20-21, 2020) (pp. 63-66). Lviv : SPOLOM. DOI: 10.31108/7.2020.14 [in Ukrainian].

12. Berezovsjka, L.I., \& Turkina, K.Gh. (2019). Psykhologhichne blaghopoluchchia majbutnikh psykhologhiv [Psychological well-being of future psychologists]. Psykhologhija nacionaljnoji bezpeky i blaghopoluchchia osobystosti: tezy I Mizhnarodnoji naukovo-praktychnoji konferenciji, 14-15 bereznja 2019 roku, Ljviv (pp. 201-203). Ljviv : Vydavnyctvo Ljvivsjkoji politekhniky [in Ukrainian].

13. Haba, I.N. (2019). Psykholohichne blahopoluchchia studentskoi molodi: hendernyi aspect [Psychological well-being of student young people: gender aspects]. Teoriia i praktyka suchasnoi psykholohii, 1 (1), 150-154 [in Ukrainian].

14. Zharikova, S.B. (2019). Henderna spetsyfika vzaiemozviazku psykholohichnoho blahopoluchchia ta dyferentsiinykh typiv refleksii u studentiv-pershokursnykiv [Gender specificity of the interrelation between psychological well-being and differential types of reflection in first-year students]. Teoriia i praktyka suchasnoi psykholohii, 6 (1), 43-46 [in Ukrainian].

15. Grankina-Sazonova, N.V. (2018). Psykholohichne blahopoluchchia ta zhyttiestiikist studentiv-psykholohiv yak vazhlyvi chynnyky osvoiennia profesii [The psychology students' psychological well-being and hardiness]. Psychological Journal, 7 (17), 23-42 [in Ukrainian].

16. Kharchenko, A.S., \& Goncharova, N.O. (2017). Osoblyvosti psykholohichnoho blahopoluchchia studentiv iz riznym typom spriamovanosti [Features of psychological well-being of students with different orientation types]. Psykholohiia i osobystist, 2 (12), 186-194 [in Ukrainian].

17. Igumnova, O.B., Dghyhun, L.M., \& Rudenok, A.I. (2020). Psykholohichne blahopoluchchia maibutnikh psykholohiv z riznymy typamy motyvatsii dosiahnen [Psychological well-being of future psychologists with different types of achieving motivation]. Visnyk Natsionalnoho aviatsiinoho universytetu. Seriia: Pedahohika. Psykholohiia, 1 (16), 164-172 [in Ukrainian].

18. Serdjuk, L.Z. (2018). Faktory psykhologhichnogho blaghopoluchchia studentiv [Factors of psychological well-being of students]. Aktualjni problemy psykhologhiji. Zbirnyk naukovykh pracj Instytut psykhologhiji imeni Gh.S. Kostjuka NAPN Ukrajiny, 6, 51-59 [in Ukrainian].

19. Huliaieva, O.V. (2018). Chynnyky psykholohichnoho blahopoluchchia u studentiv z obmezhenymy mozhlyvostiamy zdorovia [Factors of the psychological well-being of the students with disabilities]. The thesis for the Psychology candidate's degree, speciality 19.00.01. Kharkiv [in Ukrainian].

20. Titov, I.Gh., Titova, T.Je., Sedykh, K.V., Giacomuzzi, S., Ertl, M., \& Rabe, M. (2020). Psykhologhichne blaghopoluchchia osobystosti v period pandemiji COVID-19 [Psychological well-being of the individual during pandemic COVID-19]. Psykhologhija i osobystistj, 2 (18), 55-76 [in Ukrainian].

21. Polishhuk, O.M., \& Koltunovych, T.A. (2017). Osoblyvosti vzajemozv'jazku psykhologhichnogho blaghopoluchchia ta emocijnykh perezhyvanj studentiv-psykhologhiv [Features of the relationship between psychological well-being and emotional experiences of students-psychologists]. Rakursy psykhologhichnogho blaghopoluchchja osobystosti: zbirnyk tez dopovidej vseukrajinsjkogho naukovo-praktychnogho seminaru "Rakursy psykhologhichnogho blaghopoluchchia osobystosti", 9 chervnja 2017 r., Nizhyn. Nizhyn : NDU im. M. Ghogholja [in Ukrainian].

22. Danylchenko, T.V. (2017). Osoblyvosti sub'jektyvnogho socialjnogho blaghopoluchchia u studentsjkoji molodi. Suchasna molodj u socialjno-psykhologhichnomu vymiri: zdobutky chernighivsjkykh psykhologhiv (pp. 287-304). Chernighiv : Desna Polighraf [in Ukrainian].

23. Kovalenko, A.B., Ghryshhuk, E.Ju., \& Roghalj, N.I. (2020). Chynnyky psykhologhichnogho blaghopoluchchia kursantiv [Factors of military students' psychological well-being]. Ukrajinsjkyj psykhologhichnyj zhurnal, 1 (13), 85-104 [in Ukrainian].

24. Shekhovcova, N.A., Seljukova, T.V. (2020). Zadovolenistj zhyttjam i profesijnoju dijaljnistju majbutnikh pracivnykiv DSNS Ukrajiny, jaki znakhodjatjsja pid riznym stylem kerivnyctva [Satisfaction with the 
life and professional activity of future employees of the SES of Ukraine, who are under different leadership styles]. Osobystistj, suspiljstvo, zakon: tezy dop. uchasnykiv mizhnar. nauk.-prakt. konf., prysvjach. Pam'jati profesora S.P. Bocharovoji (24 kvit. 2020 r., m. Kharkiv, Ukrajina) (pp. 321-324). Kharkiv : MVS Ukrajiny, Kharkivsjk. nac. un-t vnutr. Sprav. [in Ukrainian]

25. Danilchenko, T.V. (2015). Pital'nik “Sub'ektivne sotsial'ne blagopoluchchia”: metodologichne obrruntuvannya i protsedura rozrobki [Questionnaire subjective social well-being: a methodological substantiation and working out procedure]. East European Scientific Journal, 3 (4), 20-29 [in Ukrainian].

26. Osin, E.N., \& Leontev, D.A. (2008). Aprobacija russkojazychnyh versij dvuh shkal jekspress-ocenki sub'ektivnogo blagopoluchiya [Approbation of Russian-language versions of two scales of an express assessment of subjective well-being]. In Mat-ly III Vserossijskogo sociologicheskogo kongressa (Moskva, 21-24 oktjabrja 2008 g.). [in Russian] Retrieved from: URL: http://www.hse.ru/data/2010/03/15/122895 9627/\%D0\%9E\%D181(2013):D0

27. Troshikhina, E.G., \& Manukyan, V.R. (2017). Trevozhnost' i ustoychivyye emotsional'nyye sostoyaniya v strukture psikhoemotsional'nogo blagopoluchiya [Anxiety and stable emotional states in the structure of psycho-emotional well-being]. Vestnik SPbGU, Psikhologiya i pedagogika, 7 (3), 211-223 [in Russian] doi.org/10.21638/11701/spbu16.2017.302

28. Danylchenko, T.V. (2021). Perezhyvannja osobystisnogho blaghopoluchchia na pershomu etapi pandemiji COVID-19 [Experiencing personal well-being in the first stage of the COVID-19 pandemic] (in press) [in Ukrainian].

29. Easterlin, R.A. (2005). Building a Better Theory of Well-Being. In L. Bruni, \& P.L. Porta (Eds.). Economics and Happiness (p. 29-64). Oxford : Oxford University Press.

30. Erikson, E. (1996). Detstvo i obshchestvo [Childhood and society]. M. : Lenato [in Russian].

31. Ryff, C.D., \& Singer, B. (2006). Best news yet on the six-factor model of well-being. Social Science Research, 35 (4), 1103-1119. 